\author{
Marija Savković ${ }^{1}$ \\ Aleksandar Aleksić \\ Danijela Tadić \\ Nikola Komatina \\ Tijana Cvetić
}

\title{
THE ANALYSIS OF THE IMPACT OF RECYCLING EQUIPMENT IN THE AUTOMOTIVE INDUSTRY IN TERMS OF CIRCULAR ECONOMY
}

Abstract: The main objective of this paper is the analysis of the impact of recycling equipment in the automotive industry in terms of circular economy $(C E)$. Also, paper point out the opportunities and benefits of applications equipment for recycling and principles of $C E$ in the automotive industry in Serbia. Analysis of market needs and examining the existing equipment for recycling team who work on the project TR 35033 made: mobile baling press for baling shellfish and other scrap metal, a device for dispensing oil and automatic shredder for recycling cables.

Application of the circular economy in the automotive industry is reflected in the remanufacturing a wide variety of components and parts (engines, water pumps, alternators etc.). The main benefits of applications equipment for recycling and $C E$ in the automotive industry include: maximizing the utilization of resources and increasing the reuse of materials from products that have completed their "life cycle", maximizing the life of the product, reduce environmental pollution, reducing costs etc.

Keywords: automotive industry, circular economy, end-oflife vehicle, equipment for recycling, recycling of motor vehicle

\section{Introduction}

Number of motor vehicles at the end of their life cycle in the world is increasing from year to year. According to estimates by the European Environment Agency by 2020 the number of motor vehicles at the end of life (ELV) will be around 16 million. Increasing exploitation of resources in the automotive industry increases the amount of waste. In Serbia, currently it is used 1.6 million cars, with an average age between 16 and 17 years, and recycles less than $10 \%$ of waste.
The level of resource utilization of motor vehicles at the end of the life cycle is extremely low compared to EU countries (below 60\% of the total weight of the vehicle).

The automotive industry is a major consumer of raw materials and energy resources. Research in the automotive industry are increasingly focused on the use of new materials and the reuse of secondary raw materials obtained at the end of the life cycle of the motor vehicle.

Motor vehicles at the end of the life cycle are

\footnotetext{
${ }^{1}$ Corresponding author: Marija Savković

Email: marija.savkovic@gmail.com
} 
very important sources of raw materials. The share of different material in the total weight of the disused car is: metal on the basis of iron $68 \%, 8 \%$ other metals, plastic $9 \%, 5 \%$ rubber, glass $3 \%, 2 \%$ fluids, textile $1 \%$ and others 4\% (Brzaković, 2009).

Reviewing the general situation in the recycling of used motor vehicles in Serbia can be concluded that it is not increasing the special attention to the protection of the environment. Each year, $41480 \mathrm{t}$ and $3660 \mathrm{t}$ ferrous and non-ferrous metal are losing. Also, hazardous substances are not treated on satisfactorily way. Hence, applying of equipment for recycling and principes of circular economy is gaining importance.

The establishment of an integrated and sustainable system of recycling of motor vehicles at the end of the life cycle, use of equipment for recycling and application of the principle of circular economy will contribute to maximizing the utilization of resources and increasing the reuse of materials from products that have completed their "life cycle", maximizing the life of the motor vehicle and reducing environmental pollution.

Within the project "Sustainable development of technology and equipment for the recycling of the motor vehicles" - TR 35033 was developed stable cells for detoxification of motor vehicles at the end of the life cycle, mobile baling presses for baling of shells and other scrap metal and automatic shredder for recycling cables.

Circular Economy, a concept that goes beyond the traditional linear model is based on the circulation of materials, resources, energy and their reuse through recycling already used materials and parts ie. at the end of the life cycle of the product goes back into production in order to create new value. Applying of $\mathrm{CE}$ in the automotive industry reduces the waste through the entire lifecycle of the motor vehicle. Rather than scrapping the product at the end of its life, in CE components are remanufactured to repair defects.
Also, CE enables the reuse of the parts (engine, gearbox, et al.), and recycling some of the materials (fluids, rubbers, plastics, etc.) (Simić and Stanojević, 2017). Circular Economy is applied in BMW, Renault, Fiat, Ford, Lexus, Porsche, Suzuki, Mercedes Benz, Volvo, Chevrolet etc.

The paper is structured as follows: After the introduction, the first part of the paper describes the process of recycling of motor vehicles and presents the equipment for recycling of the motor vehicles at the end of the life cycle, that was developed within the project TR 35033.

Second part of the paper presents the concept of circular economy, history $\mathrm{CE}$, the basic characteristics of the $\mathrm{CE}$ and legislation in this field. In the second part of the paper the comparative analysis of the linear model and the model of the circular economy is given. Also, in this part of the paper authors point to the benefits of $\mathrm{CE}$ applications in the automotive industry. In conclusion, the authors present concluding observations of this area and points to future directions of research in this area.

\section{Equipment for recycling in automotive industry in Serbia}

Recycling involves a set of activities that allow the preparation of similar materials (metals, plastics, rubber, etc.), suitable for manufacturing the new product (Brzaković, 2009).

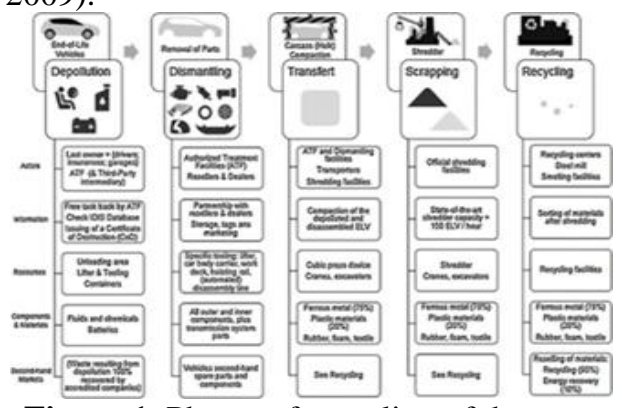

Figure 1. Phases of recycling of the motor vehicle at the end of life (Saidani, 2017). 


\section{Intermational Qualilty Conference}

QUA I I I I Y

Recycling of the motor vehicle at the end of the life cycle is carried out in several stages (Pavlović, 2011):

- delivery motor vehicles for recycling,

- the removal of working fluid,

-dismantle the motor vehicle on the components,

- cutting,

- sorting and

- processing (Picture 1).

In stage detoxification all potentially hazardous components from vehicles are removed- battery, fuel, lead weights for balancing wheels, potentially explosive components (e.g., airbag), the components which contain mercury, all kinds of fluid (fuel, all kinds of oils, refrigeration fluid, antifreeze, washer fluid windshield), oil filters, unless some of these components can be reused as spare parts. Implementation of equipment for the detoxification allows to recover more than $98 \%$ of the fluid in a relatively short period of time (20-30 $\mathrm{min}$ in the motor vehicle) (Simić et al, 2013).

Companies "Seda" and "Vortex" produce specialized equipment for detoxification of motor vehicles- stations and mobile devices for detoxification vehicles. Following the example of their technology within the project TR 35033 was developed stable cells for detoxification of motor vehicles at the end of the life cycle, weighing less than $3 \mathrm{t}$. The characteristics of the plant include: the possibility of rotation of the carrier about the horizontal plane of the motor vehicle to $6^{\circ}$, the treatment times of a motor vehicle is 20 minutes, the volume of dispensed fluid receiving reservoir is 891 , the ability to add new tank for receiving a fluid to the channel (Simić et a., 2013).

Plant for removing fluid from the motor vehicle at the end of the life cycle consists of: a compressor with a tank, bund, bracket car with a hydraulic power unit, funnels to collect oil and brake fluid reservoir for accepting discharged fluid from the vehicle, drill rig fuel, needles for discharging coolant and distribution strips with the carrier (Simić et al, 2013).

In the third phase the motor vehicle is separated into the components and the parts (eg. the battery, wheels, motor, bumpers, electrical switches, the gear unit, the alternator, the plastic parts, glass, electronics and cables electrics, pneumatics, fuel tank, air-conditioning, etc.) (Simić and Stanojević, 2017). One or more components can be reused as spare parts (catalysts, metal parts which containing copper, aluminum and magnesium...). Rules define which parts must not be reused because the safe operation of the motor vehicle dependends directly on them. The subsequent removal of non-metallic parts (plastic, glass, leather, textiles, wood ...) are performed.

The motor vehicle is then transported to shredding which is performed by Schredder, scissors or mills. Equipment used for crushing have the large dimensions and complex structures (Simić et al, 2013; Simić and Stanojević, 2017). Shredder enables recycling of motor vehicles and other metal waste by grinding, sieving, milling, and crushing with a large number of rotating hammers (Simić et al, 2013;).

The main products of recycling in the plant Schredder are (Simić and Stanojević 2017):

- fractions of magnetic waste (iron and steel), about $70 \%$,

- mixed fractions of non-magnetic metal (aluminum, copper, etc.), maximum $6.4 \%$,

- light fractions from Shredding systems (PVC, polyurethane, glass, ceramics, paints, etc.) (about 23\%), and

- iron with content of a copper from 0.2 to $0.3 \%$ which may be used for further processing.

Depending on whether water is added before the grinding process in order to minimize the impact of potential explosions and minimize the amount of dust, shredders are divided into wet schredder, schredder with wetting and dry schredder. 
Recycling of electrical and electronic waste is particularly important as this waste contains extremely valuable materijalecopper, gold, silver, platinum etc. The cables are usually improperly incinerated in order to reach the precious copper, and it negatively affects on the environment (Simić et al., 2013). Burnt plastic can be used as a secondary raw material. Shredders separate the copper from the plastic lining products. Shredder provided the separated copper and granulate suitable for further treatment. Within the project "Sustainable development of technology and equipment for the recycling of the motor vehicles" - TR 35033 was developed automatic shredder for recycling cables.

In order to optimize the transport of scrap metal and facilitate its packaging baling is carried out. Due balers are extremely expensive baling can implement by a system utility baling. Within the project TR 35033 was developed mobile baling presses for baling of shells and other scrap metal. Output from these presses represent bale dimensions (1050x500x800-1200) mm suitable for further packaging (Simić and Stanojević, 2017).

After shredding, the ferrous and nonferrous metals are separated. The residue that remains after this separation represents unusable residue (ASR- automotive shredder residue). ASR can amount to $15-20 \%$ of the total weight of the motor vehicle (Simić et al., 2013). In Serbia, there is no facility for treatment of ASR and therefore opens up the possibility of development of this equipment in the future (Simić et al, 2013).

In the last step, the processing of waste materials is performed. These materials can be recycled and again used in the manufacture of motor vehicles (Simić and Stanojević, 2017).

In order to define a responsible attitude towards waste which produce motor vehicles at the end of its life cycle the European Parliament in September 2000 adopted End of Life Vehicles - ELV-Directive
2000/53/EC. This Directive lays down measures to reduce waste originating from vehicles that have reached the end of its life cycle, increase reuse of perts and reduce the negative environmental impact.

In Serbia in 2008. a new Law on Waste Management was adopted. Laws that are relevant for the recycling of used motor vehicles are: Law on Environmental Protection and the Law on the treatment of waste materials.

The main objective of waste management strategy for the period 2010-2019. was the establishment of an economically sustainable system for the recycling of motor vehicles at the end of the life cycle. From January 2015, the rate of recycling and recovery rate must not be less than $80 \%$ and $85 \%$, respectively, while the rate of energy recovery can not be greater than 5\%. Since January 2019, the minimum rate of recycling and recovery increase to $85 \%$ and $95 \%$ respectively (Pešić).

Issuing regulations about way and procedure for the management of motor vehicles at the end of the life cycle of Serbia has adopted a system to management of the motor vehicle at the end of the life cycle modeled on the European Directive 2000/53/EC with a slightly longer timeframe to achieve some degree of recycling (Pešić, Simić et al, 2013). In 2010 Regulations on the way and procedure for management of waste of the motor vehicles; Regulations on way and the procedure for the management of waste of tires; Regulations on way and the procedure for the management of spent batteries and accumulators; Regulations on conditions, way and the procedure management of a waste oil; and Regulations on the treatment of waste products with hazardous substances were adopted.

\section{Circular economy}

During the last 5-10 years, the concept of the "circular economy" has received growing attention. CE is first applied in Germany. In 


\section{Intermational Quality Conference}

1996 a law on a closed cycle of waste management was passed. In Japan in 2000. the Law on the establishment of a society based on recycling was adopted. The greatest progress in the transition towards a circular economy have made China and the countries of the European Union.

In 2014. the European Commission has adopted a Communication "Towards a circular economy: a zero waste program for Europe" in order to establish a common and coherent EU framework for the promotion of circular economy (Carapina, 2015).

At the end of 2015. the European Commission adopted a package of measures to encourage the EU to pass a circular economy in order to improve competitiveness, create jobs and establish sustainable growth. This package of measures promote an increasing in the recycling of waste instead of its disposal at the landfill, which the circle of life of the product closes.

In the linear model the movement of resources takes place in one direction. The major paradigm of the linear model is: takemake-dispose. Natural resources are used to produce products. After the expiry of the "lifetime of product", the product is disposed of in landfills and thus the cycle, which is initiated by providing the appropriate raw materials is finished.

The linear model is unsustainable because it generates large amounts of waste (increasing resource exploitation increases the amount of waste) and it does not comply with sustained economic growth, environmental protection and societal wellbeing. This model is based on the belief that resources are inexhaustible and there is unlimited space for waste disposal (Despeisseet al., 2015).

The concept of circular economy beyond the traditional linear model (Gligorić et al., 2017). The major CE paradigm is: take -do fix - reuse - recycle. CE includes transformation of the "resource-productspollution" mode to "resource-productsregenerated resources".
Circular economy includes the circular movement of resources and energy and their reuse through recycling already used materials and parts ie. at the end of the life cycle the product goes back into production in order to create new value (Gligorić et al., 2017). CE is based on reducing wasteful resources through effective design of products for improved resource-efficiency with circular material flow involving recovery, reuse, recycling and remanufacturing of products. In CE products and the materials are valuabble after use, unlike in the linear economic model.

Circular economy model is presented in figure 2. (Ellen Macarthur Foundation, 2013).

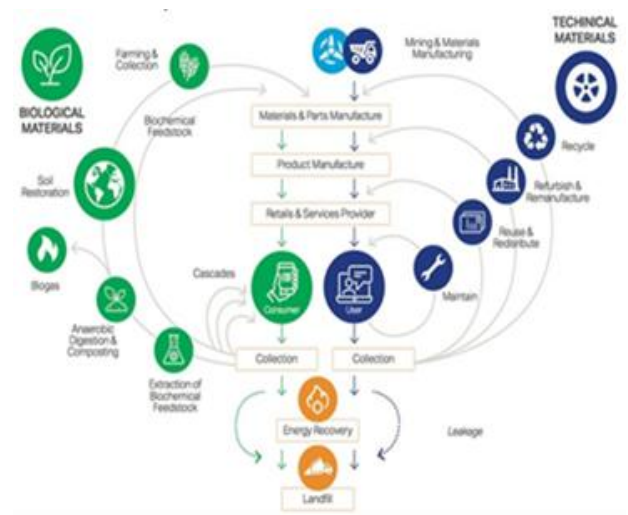

Figure 2. Model of circular economy

Circular Economy enables to minimizing waste, which can not be re-used across all four faze- product design, production, use and waste management. All stages of production of products according to a circular economy are interrelated (Despeisseet al., 2015; Ellen Macarthur Foundation, 2013). The waste from one manufacturing process comes as a resource to another. In the design phase the ways a combination of resources in production, the possibility of recycling and reuse, the ability to repair and return the product to the market are defines.

In the CE products are designed to be easily reused, divorce, repaired or recycled. In the production, resources are transformed in 
order to effectively use. In doing so, using the renewable energy (Carapina, 2015).

In linear economy model, products are recycled or discarded when a part fails. In a circular economy the product and its components are remanufactured when they breakdown (Cirkularna ekonomija kao šansa za razvoj Srbije, 2017). Comparative analysis of linear and circular economy is shown in figure 3 .

\begin{tabular}{|l|l|}
\hline \multicolumn{1}{|c|}{ Linear model } & \multicolumn{1}{|c|}{ Circular economy } \\
\hline $\begin{array}{l}\text { The model is based on } \\
\text { the philosophy of take- } \\
\text { use-dispose }\end{array}$ & $\begin{array}{l}\text { The model is based on } \\
\text { the avoidance of waste } \\
\text { and roundabout of } \\
\text { resources, which is } \\
\text { continuously returned } \\
\text { to the production } \\
\text { process }\end{array}$ \\
\hline $\begin{array}{l}\text { This model does not } \\
\text { take into account the } \\
\text { limited natural } \\
\text { resources, renewable } \\
\text { energy, product design } \\
\text { and application of } \\
\text { natural materials }\end{array}$ & $\begin{array}{l}\text { The focus is on the use } \\
\text { of renewable energy } \\
\text { sources and natural }\end{array}$ \\
\hline $\begin{array}{l}\text { The products are used } \\
\text { once }\end{array}$ & $\begin{array}{l}\text { It is based on the } \\
\text { repeated use of the } \\
\text { product, extending its } \\
\text { "lifetime" }\end{array}$ \\
\hline
\end{tabular}

Figure 3.- Comparison of models of linear and circular economy

Benefits of circular economy are reflected in maximizing the utilization of resources and increasing the reuse of materials from products that have completed their "life cycle" (Carapina, 2015), maximizing the life of the product, reduce environmental pollution, the use of renewable energy, reducing costs (Gligorić et al., 2017). The results of CE include savings of $90 \%$ in energy, $40-70 \%$ in the material, if necessary, $30-60 \%$ of waste treatment to eliminate pollution, and increase the profit of $9-26 \%$ (Cirkularna ekonomija kao šansa za razvoj Srbije, 2017).

In a perfect circular economy, a motor vehicle go through three stages (3R-ReduceReuse-Recycle) (Pešić). Utilizing the 3R principles enable production by utilizing reduced natural resources, producing minimum pollutions, emissions and wastes. The first $\mathrm{R}$ refers to the reduced use of energy, materials and other resources during manufacturing, and the reduction of emissions and waste during the use stage. Reduce refers to designing cars that will have a longer life and use less resources. Second $\mathrm{R}$ represents the reuse of individual parts and components as spare parts. Reuse refers to the reuse of the whole vehicles, or its components, after its first life-cycle (Ellen Macarthur Foundation, 2013). Reuse is planned in the design process so that the product can be disassembled easily and its components repurposed to produce newer products and components with the minimum amount of waste (Pešić). Finally, the parts are recycled- turn in the materials from which they were originally obtained. All automotive steels are fully recyclable and can be easily separated from other materials and recovered with a magnet (The circular economy- ArcelorMittal Automotive Europe).

The concept of 3R Toyota is advanced into the $5 R$, which in addition to these three $R$ includes filtering materials for ease of recycle, and process of recovery energy from the waste, resulting from the treatment of waste of the motor vehicle in order to reduce $25 \%$ of the residue (Pešić et al, 2009; Brzaković et al., 2009).

Applying of $\mathrm{CE}$ in the automotive industry reduces the waste through the entire lifecycle of the motor vehicle, enables the reuse of the parts (engine, gearbox, et al.), and recycling some of the materials (fluids, rubbers, plastics, etc.) (Simić and Stanojević, 2017). Circular Economy is applied in BMW, Renault, Fiat, Ford, Lexus, Porsche, Suzuki, Mercedes Benz, Volvo, Chevrolet etc.

Renault's philosophy is "Nothing goes to waste in a natural cycle". Everything is reused, composted or digested. Circular economy model in Renault includes a processing engine parts, creating a "second life" for batteries and increase the recycling of raw materials (steel, copper and plastic) in a way that it is possible to keep in the 


\section{Intermational Quality Conference}

QUA IITY

automotive industry. $36 \%$ of the total number of finished products are produced from recycled materials. Also, Renault plans to increase the amount of recycled plastic for $15-20 \%$. A car can be made at a minimum cost in energy terms by integrating the car itself into the ongoing production process.

Finding a use for decommissioned airbags Volvo takes another step towards a circular economy (Volvo Group, 2015). If an airbag was designed so its fabric can be reused, it gets a second life even before it's made. Also, materials from scrapped cars used for make new products. BMW has been very responsible to regarding implementing the circular economy. The main reasons of development of I-series vehicles is to implement the circular economy by producing the light-weight and electronic vehicles which will help to consumed low product material and also decrease the $\mathrm{CO} 2$ emission.

Serbia has accepted the EU's recommendations on circular economy (FCA-CIRCULAR ECONOMY). However Serbia currently characterized by lack adequate institutional environment for the realization of $\mathrm{CE}$. Circular economy model is applied in FCA. FCA promotes biomethan as an alternative and renewable fuel that reduces environmental pollution (FCACIRCULAR ECONOMY). Biomethane is obtained by upgrading biogas, which is produced from various types of organic waste. All of FCA's natural gas models can run on biomethane. Application of circular economy in the manufacture of tires and other rubber products, and waste management in this industry is still in its infancy. Only $5 \%$ of waste from the rubber returns to a new product.

\section{Conclusion}

Recycling of motor vehicles allows to recovering materials in the production cycle for the production of new parts for the vehicle. Ecological effects of recycling are manifested through the reduction of harmful impacts of motor vehicles at the end of the life cycle on the environment. Comparing the recycling of motor vehicles in Serbia and in other developed countries, there could be concluded that Serbia must improves recycling of ELV and improves the equipment used for the recycling of vehicles at the end of the life cycle.

Application of equipment for the recycling of motor vehicles at the end of the life cycle contributes to increasing the efficiency of recycling. Within the project "Sustainable development of technology and equipment for the recycling of the motor vehicles" - TR 35033 was developed stable cells for detoxification of motor vehicles at the end of the life cycle, mobile baling presses for baling of shells and other scrap metal and automatic shredder for recycling cables. However, there is no facility for treatment of ASR and therefore opens up the possibility of development of this equipment in the future. Changes to the motor vehicle structure and application of new materials in the production process cause the constant development of recycling technology and equipment for recycling.

Circular economy includes the circular movement of resources and energy and their reuse through recycling already used materials and parts. CE maximizes the utilization of resources and increases the reuse of materials from products that have completed their "life cycle", reduces energy consumption, decreases pollution, contributes to increasing overall resource efficiency and environmental performance.

Future directions of research in this area will be focused on detailed research contribution Of $\mathrm{CE}$ in increasing the efficiency of recycling and reducing environmental pollution.

Acknowledgment: Research presented in this paper was supported by Ministry of Science and Technological Development of 


\section{Interinational Quality Conference \\ Republic of Serbia, Grant TR-35033, vehicles recycling technology and}

Title:Sustainable development of motor equipment.

\section{References:}

Brzaković, R., Marjanović, Z. (2009). Reciklaža kao segment životnog ciklusa vozila, I nacionalna konferencija o reciklaži motornih vozila, Ečka

Bonciu, F., (2014). The European economy: from a linear to a circular economy. Roman. J. Eur. Affairs 14 (4), 78-91

Blomsma, F., Brennan, G., (2017). The emergence of circular economy: a new framing around prolonging resource productivity. J. Ind. Ecol. 21 (3), 603-614

Buruzs A., Torma A., (2017), A Review on the outlook of the circular economy in the automotive industry, World academy of science, engineering and technology, International journal of environmental and ecological engineering vol.11, No.6, pp.576-580

Carapina H., Mihajlov A., (2015), U susret konceptu cirkularne ekonomije : uloga sistema upravljanja otpadom, Međunarodna konfrencija : otpadne vode, komunalni čvrsti otpad, Zbornik radova, s.171-177; ISBN 978-86-82931-68-3, At Budva, Montenegro, Volume: I

Cirkularna ekonomija kao šansa za razvoj Srbije (2017), Organization for Security and Cooperation in Europe, available on https://www.osce.org/sr/serbia/292311

Ćurčić S., Arsovski S., Pavlović M.,Lazić M., Ivanović L.(2012) Održivi razvoj tehnologija i opreme za reciklažu motornih vozila, Elaborat projekta TR 35033, FTN-Čačak

Ćurčić S., Paunović L., Recycling of the end-of-life motor vehicles-situation in Serbia, Informacione tehnologije, obrazovanje i preduzetništvo, pp.547-552

Despeisse M.,Yusuke K., Nakano M, Barwood M., (2015) Towards a circular economy for end-of-life vehicles: A comparative study UK - Japan, The 22nd CIRP conference on Life Cycle Engineering, Procedia CIRP 29 pp.668-673

Ellen Macarthur Foundation (2013), Towards the Circular Economy: Economic and Business Rationale for an Accelerated Transition

European Comission (2014), Towards a circular economy: A zero waste programme for Europe. Brussels, pp. 2, 2.7.2014 COM 398 final. [Online]. Available at: $\mathrm{http} / / / \mathrm{ec}$.europa.eu/environment/circulareconomy/pdf/circulareconomy-communication.pdf

FCA-CIRCULAR ECONOMY: The Natural Approach to Sustainable Value, https://www.fcagroup.com/enUS/media_center/insights/Pages/circular_economy_biomethan e.aspx

Ghisellini, P., Cialani, C., Ulgiati, S., (2016), A review on circular economy: the expectedtransition to a balanced interplay of environmental and economic systems. J. Clean.Prod. 114, 11-32

Gligorić M., Jovanović-Gavrilović B. (2017), Cirkularna ekonomija kao okosnica održivog razvoja privrede Srbije, Ekonomski vidici, vol. 22, br. 2-3, str. 119-134

Hughes R., The EU Circular Economy package - life cycle thinking to life cycle law? (2017),

The 24th CIRP Conference on Life Cycle Engineering, Procedia CIRP 61, pp. 10 - 16

Kirchherr J., Reike D., Hekkert M., (2017) Conceptualizing the circular economy: An analysis of 114 definitions, Resources, Conservation \& Recycling. pp.221-232

Meric S., Selcuk H., Onat B., Ongen A., Sustainable technologies for recycling and reuse: an overview, Environmental Science and Pollution Research, 2018, Volume 25, Issue 4, pp. 2993-2995

Mitrović S., Radosavljević I.,Veselinov M., (2017), Cirkularna ekonomija kao šansa za razvoj Srbije, Organization for Security and Co-operation in Europe, mission in Serbia, brošura, 
https://www.osce.org/sr/serbia/292311

Milivojević, J., Grubor, S., Kokić Arsić, A., Đokić, S., Tonić, N., (2011), Reciklaža motornih vozila na kraju životnog ciklusa u funkciji kvaliteta života, Festival kvaliteta, Šesta nacionalna konferencija o kvalitetu života, Kragujevac

Milivojević J., Grubor S., Kokić-Arsić A., (2008), Razvoj integrisanog i održivog sistema reciklaže motornih vozila na kraju životnog ciklusa u Srbiji, 3.Nacionalna konferencija o kvalitetu života,Festival kvaliteta, Kragujevac

Pavlović M., Karanović N., Đurić A., (2011) Uputstvo za detoksikaciju motornih vozila na kraju životnog ciklusa u skladu sa pozitivnim zakonodavstvom Republike Srbije - deo projekta "Postavljanje održivog modela reciklaže motornih vozila u Banatu u skladu sa novim nacionalnim zakonodavstvom"

Pešić R., Babić S., Milosavljević B., Reciklaža u automobilskoj industriji, Kvalitet-časopis za unapređenje kvaliteta, Vol.19, No.5-6, pp. 76-80

Saidani M., Yannou B., Leroy Y., Cluzel F., (2017), Heavy vehicles on the road towards the circular economy: Analysis andcomparison with the automotive industry, Resources, Conservation \& Recycling

Simić, M., Tomović, A., Pavlović, M., Tehno-ekonomska analiza opreme za reciklažu motornih vozila na kraju životnog ciklusa, S-kriva, - Zbornik radova 38. Nacionalne konferencije o kvalitetu „Festival kvaliteta“, Kragujevac, 2013, str. 442-450.

Simić, M., Tomović, A., Pavlović, M., (2013), Prisutna oprema u reciklaži motornih vozila usaglašena sa zakonodavstvom, - Zbornik radova 38. Nacionalne konferencije o kvalitetu „Festival kvaliteta“, Kragujevac, str. 427-432.

Simić, S.; Stanojević, M. (2017), Uspostavljanje integrisanog i održivog sistema reciklaže motornih vozila na kraju životnog ciklusa značajan segment zaštite životne sredine. Zbornik Međunarodnog kongresa o procesnoj industriji- Procesing, v. 25, n. Available on: https://izdanja.smeits.rs/index.php/ptk/article/view/2384

The circular economy - ArcelorMittal Automotive Europe, https://automotive.arcelormittal.com/Sustainability/circulareconomy

Towards a circular economy: A zero waste programme for Europe Brussels, 25.9.2014 COM (2014) $398 \mathrm{final} / 2$

Tolmač D., Prvulović S., Pavlović M., Dimitrijević D., (2011),Analysis of recycling car in Serbia and review of optimal technology, Facta universitatis, Series: Mechanical Engineering, Vol. 9, No 2, pp. 215 - 228

Vermeulen I., Caneghem Van J., Block C., Baeyens J., Vandecasteele C. Automotive shredder residue (ASR): Reviewing its production from end-of-life vehicles (ELVs) and its recycling, energy or chemicals' valorisation. Journal of Hazardous Materials 190 (2011) pp. 8-27

Volvo Group, 2015. The volvo group annual and sustainability report 2015. Report 22 


\section{Marija Savković}

University of Kragujevac, Faculty of engineering,

Kragujevac,

Serbia,

marija.savkovic@kg.ac.rs

\section{Nikola Komatina}

University of Kragujevac,

Faculty of engineering,

Kragujevac,

Serbia,

nkomatina@kg.ac.rs
Aleksandar Aleksić

University of Kragujevac,

Faculty of engineering,

Kragujevac,

Serbia,

aaleksic@kg.ac.rs

\section{Tijana Cvetić}

University of Kragujevac,

Faculty of engineering,

Kragujevac,

Serbia,

t.cvetic@kg.ac.rs

\section{Danijela Tadić}

University of Kragujevac,

Faculty of engineering,

Kragujevac,

Serbia,

galovic@kg.ac.rs 